PRODUCTION

ENGINEERING

ARCHIVES
2016, Vol.11, No 2, pp 40-43

ISSN 2353-5156 (print version)

ISSN 2353-7779 (online version)

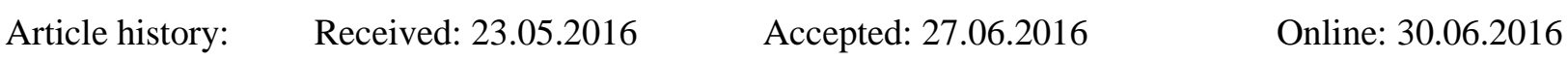

Available online on: http://www.qpij.pl

Exist since $4^{\text {rd }}$ quarter 2016

\section{Management aspects of the heating system work}

\author{
Aleksandra Rak \\ Institute of Production Engineering, Częstochowa University of Technology, Armii Krajowej 19B, Poland, e-mail: arak@ fluid.is.pcz.pl
}

\begin{abstract}
The article discusses the problems of optimization and management of a centralized heating system. It characterizes the heating systems and the process of heat supply. The work focuses on identifying the components of the comprehensive analysis of thermal systems, considering the heat market analysis and processes in district heating networks. It presents the ways of estimating the heat demand in the district heating system.
\end{abstract}

Key words - district heating system, optimization and management, information systems, thermal energetics

\section{Introduction}

Heat industry is one of the major subsystems of the national energy system. It fulfils the needs of society and industrial customers. In Poland, heat is produced either in centralized sources (heating system) or locally (Fig. 1).

Centralized heating systems in Poland cover on average $65 \%$ of the heat demand. These are city power plants which provide hot water with cogeneration of electricity (NIEDZIÓŁKA D. 2010).

The energy efficiency of heating systems in Poland is unsatisfactory. It is necessary to modernize and transform them, in accordance with the strategy of sustainable development. This requires the efficient use of non-renewable primary energy sources, replacing them with renewable media sources (RES), implementation of information technology to optimize the heating network and realize the concept of Smart Grid.

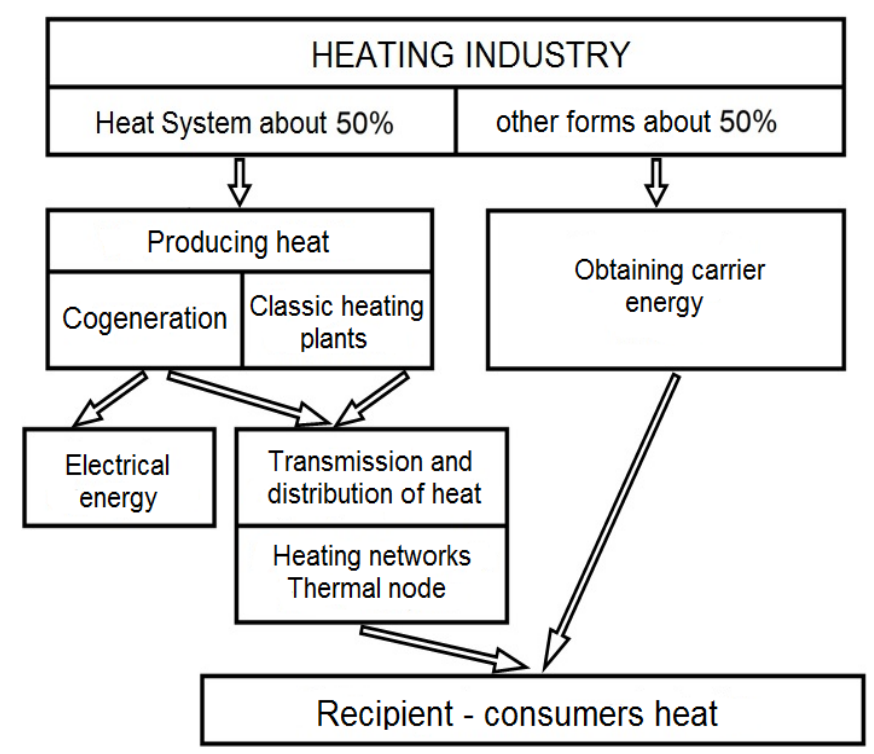

Fig. 1. Schematic diagram of a heat supply Source: SZYMCZAK J., REGULSKI B. 2014 


\section{The characteristics of the heating system}

The process of supplying customers with heat is carried out by the district heating system including the essential elements to ensure the continuity and quality of supply of heat (KUCZYŃSKI T., ZIEMBICKI P. 2012):

- the source of thermal energy supply,

- heating network distributing heat carrier (most often water, less often water vapour)

- district heating substations adjusting the parameters of the heat carrier to the requirements of customers

- internal installations in buildings supplying individual receivers.

Schematic diagram of the heating system is shown in Figure 2.

A local boiler, heating plant, power plant or a nu-

pending on the main line connection, the network has a radial arrangement (main line doesn't connect with each other) or a ring arrangement (main line are connected).

Because of the high pressures and temperatures of the heat carrier in heating network, heat receivers are usually connected by an adapter, which is the node heating. The main element of the heat is heat exchanger or a stream pump.

\section{Operation and management of heat- ing systems}

At present, the energy sector faces the challenge of strategy execution, the Polish energy policy until 2030 and the implementation of a legal system based on the directive on energy efficiency. The effect is to improve energy efficiency and reduce the negative impact on the environment (POLITYKA ENERGETYCZNA POLSKI DO 2030 RoKU. 2010). The law on energy efficiency executed by Poland in 2011, determines the national target for efficient energy management with activities aimed at improving energy efficiency (USTAWA O EFEKTYWNOŚCI ENERGETYCZNEJ, DYREKTYWA IW SPRAWIE EFEKTYWNOŚCI ENERGETYCZNEJ).

Companies of the heating sector are compelled by conditions and requirements to introduce structural and organizational transformations. The investment pro-

clear reactor can be used as a source of heat, also referred as to central heat. These systems are often called sources of power industry (NANTKA M.B. 2013).

District heating is a system of pipelines transporting heat carrier, that is hot water (water networks) and water vapour (steam network). The most common remote system is a two-wire water network in a closed system, i.e. the main line, connecting the heat source with recipients, which has two wires: supply and return, with water flow forced by a pump station. De- jects are undertaken by the modernization of heating networks infrastructure and the use of telemetry and information technology.

Implementation of software packages dedicated to the heating sector provides current control of the operating status of heating systems and offers new possibilities for the analysis and control of their work. They give possibility to simulate static and dynamic conditions occurring in real heating systems. Currently on 
the market there are several advanced programs for modelling and optimization of district heating networks available, such as Bentley SisHYD, which is operated by heat suppliers in the Nordic countries and the program TERMIS tested in Polish district heating networks.

Heat loss in district heating systems is a major issue concerning the efficiency of heat transfer to final users. There are three main areas to ameliorate the heating system energetic efficiency and associated methods of its improvement (JACHURA A., SEKRET R. 2015):

- the heat source - improving energy efficiency includes the development of combined generation of heat, electricity and cooling energy (cogeneration systems, trigeneration), the change of energy conversion technology and the use of fuels with a lower environmental load,

- heating network - creating new regulatory tables, based on lower operational parameters of the heating network, the use of simulation methods for forecasting demand for heat, the creation of intelligent heating networks (smart grids), reducing heat loss through replacing exploited heating pipelines, made in the channel technology, with a pre-insulated network

- recipient (construction - installation system) - undertaking thermomodernization with the implementation of the low energy construction standard in order to reduce the demand for heat.

\section{Estimating the demand for heat}

The total heat demand in district heating systems is the sum of customers' thermal needs resulting from space heating, water heating, mechanical ventilation and technological purposes.

Heat balance in the system is described by the formula (RAK A. 2015):

$Q_{w}=Q_{L i c}+\sum_{i=1}^{n} Q_{r s i}+\Delta Q+\sum_{j=1}^{k} Q_{r s j}+\Delta q+Q_{p w}+Q_{\dot{z}}$

where:

$\mathrm{Q}_{\mathrm{w}}$ - the heat generated in the heating system,

$\mathrm{Q}_{\text {Lźc }}$ - the heat stored in the tray heat,

$\mathrm{Q}_{\mathrm{rsi}}$ - heat transferred to another recipient in a node network.

$\Delta \mathrm{Q}$ - combined heat loss in the district heating network transmission main line,
$\mathrm{Q}_{\mathrm{rsj}}$ - heat transferred to another recipient in the external instalation,

$\Delta q$ - combined heat loss in the interior of receiving installation,

$\mathrm{Q}_{\mathrm{pw}}$ - heat used for own system

$\mathrm{Q}_{\mathrm{Z}}$ - heat used in the source.

Regarding heat transfer in the heating network, the equation (1) can be converted to the form:

$$
Q_{z}=\sum_{i=1}^{n+k} Q_{r s i}+\sum \Delta Q
$$

where:

$Q_{z}=Q_{w}-Q_{L \dot{z} c}-Q_{p w}-Q_{\dot{z}}-$ heat delivered to the network,

$\sum \Delta Q=\Delta Q+\Delta q-$ combined heat loss in the main line transmission and receiving systems.

The consumption of heat during a heating season is directly dependent on the length of the season and an outside air temperature. A demand for heat in the heating system changes in time and is conditioned by several factors, mainly external ones. The process of heat transfer in equilibrium as a balance of power is described by the formula (RAK A. 2015):

$$
P_{z}-\Delta P_{s}=K_{w \Sigma} \cdot N_{z \Sigma}
$$

where:

$P_{z}$ - heat load network (thermal power transmitted to the network, ie. the power generated net)

$\Delta P_{s}-$ transmission power losses,

$K_{w \Sigma}$ - average utilization coefficient of thermal power,

$N_{z \Sigma}$ - total ordered thermal power in the network.

The amount of ordered thermal power results from consumers' demand for the thermal energy. The level of heat consumption for individual rooms and buildings is determined by the amount of heat losses resulting from penetration through the walls, windows and roof, the losses resulting from leakage, including heat gains from solar radiation and operating profits (FOIT H., ŚWIERC W. 2012, KALKULATOR ENERGETYCZNY. 2015, STRZAŁKA A. 2013).

\section{Summary and conclusions}

The near future is to equip heating systems with more modern monitoring infrastructure and to integrate the management of its individual elements from a distance. The remote control of heat nodes and pump- 
ing stations will be possible due to telemetry and telecontrol solutions. Intelligent management of the system will allow the operator to respond faster and to react more flexibly to rapidly changing network parameters and instantaneous changes of the heat demand (BALAS P., Falba Ł. 2016). Comprehensive support in making decisions based on historical and weather data and operating the system in a real time will enable more efficient heating network management. The main benefits are: energy savings, maintaining thermal comfort and reduction of heat loss by penetration. This will also fulfil the EU requirements regarding carbon emission reduction.

\section{Literature}

1. Balas P., FAlBA Ł. 2016 Inteligentna Sieć Ciepłownicza $w$ Warszawie - charakterystyka projektu modernizacji Warszawskiej sieci ciepłowniczej, Instal $1 / 2016$.

2. Dyrektywa Parlamentu Europejskiego i Rady 2012/27/UE z 25 października 2012 roku w sprawie efektywności energetycznej, zmiany dyrektyw 2009/125/WE i 2010/30/UE oraz uchylenia dyrektyw 2004/8/WE i 2006/32/WE (Dz.U. UE L 315 z 14.11.2012 r.).

3. FOIT H., ŚWIERC W. 2012 Wyznaczanie wymaganej mocy źródła ciepła na potrzeby diagnostyki cieplnej budynku mieszkalnego, „Rynek Energii”, nr 5(102),

4. Instytut Energetyki Oddział Gdańsk, Kalkulator energetyczny dla jednostek samorzadu terytorialnego, raport nr ew. OG/259/15, Gdańsk 2015, http://www.ien.gda.pl/pl/page/709, raport_finalny.pdf [dostęp: 27.07.2016].

5. JACHURA A., SEKRET R. 2015 Poprawa wykorzystania mocy cieplnej miejskiego systemu ciepłowniczego poprzez uwzględnienie krótkookresowego zapotrzebowania na ciepło, ,Rynek Energii”, nr 5 (120).

6. KUCZYŃSKI T., ZIEMBICKI P. 2012 Inteligentne systemy ciepłownicze zintegrowane $w$ ramach smart grid, „Ciepłownictwo, Ogrzewnictwo, Wentylacja” nr 43/9.

7. Polityka energetyczna Polski do 2030 roku. Załącznik do obwieszczenia Ministra Gospodarki z 21 grudnia 2009 roku (MP z 2010, nr 2, poz. 11).

8. RAK A. 2015 Wybrane aspekty techniczne poprawy efektywności energetycznej miejskiego systemu cie- płowniczego, "Między ewolucją a rewolucją - w poszukiwaniu strategii energetycznej, J. Maj, P. Kwiatkiewicz, R. Szczerbowski (red.), Poznań.

9. StrZAŁKA A. 2013 Wplyw parametrów eksploatacyjnych na efektywność sieci grzewczej osiedla Scharnhauser Park, rozprawa doktorska, Politechnika Opolska, Opole 2013, s. 11.

10. SzYMCZAK J., REGULSKI B. 2014 Najwyższy czas na odpowiednie uznanie pozycji ciepłownictwa $w$ Polityce Energetycznej Polski, „Ciepłownictwo, Ogrzewnictwo, Wentylacja".

11. Ustawa z dnia 15 kwietnia 2011 r. o efektywności energetycznej (Dz.U. z 2011 r., nr 94, poz. 551). 